\title{
THE AMAZON SAILFIN CATFISH PTERYGOPLICHTHYS PARDALIS \\ (SILURIFORMES: LORICARIIDAE), A NEW EXOTIC SPECIES ESTABLISHED IN THE DOMINICAN REPUBLIC
}

\section{El pez gato acorazado del Amazonas Pterygoplichthys pardalis (Siluriformes: Loricariidae), una nueva especie exótica establecida en República Dominicana}

\author{
Patricia Torres-Pineda ${ }^{1,{ }^{*}}$, and Jonathan W. Armbruster ${ }^{2}$
}

\begin{abstract}
${ }^{1}$ Museo Nacional de Historia Natural "Prof. Eugenio de Jesús Marcano", Plaza de la Cultura, Santo Domingo, 10204, Dominican Republic; (D) orcid.org/0000-0002-7921-3417. ${ }^{2}$ Museum of Natural History, Department of Biological Sciences, Auburn University, Auburn, 36849, Alabama, United States; (i) orcid.org/0000-0003-3256-0275. *For correspondence: p.torres@mnhn.gov.do.
\end{abstract}

\section{ABSTRACT}

The correct identity and occurrence of the introduced armored catfish, locally known as "devil fish" or "pleco" in the Dominican Republic, is briefly described. Specimens were collected from six sites in the Dominican Republic. Several meristic and morphometric characters, as well as other external features including coloration, were examined. Results were compared with existing literature on fishes of the family Loricariidae. Examination revealed that specimens of the armored catfish, unofficially reported as Hypostomus plecostomus, actually belongs to the species Pterygoplichthys pardalis (Castelnau, 1855). It is inferred that this fish is established in Dominican inland waters, also the possibe occurrence of more than one species of Pterygoplichthys is discussed. This is the first report of this invasive species in the island of Hispaniola.

Keywords: Armored catfish, Caribbean, Hispaniola, invasion, introduced species.

\section{RESUMEN}

Se describe brevemente la identidad correcta y la presencia del pez gato acorazado introducido, localmente conocido como "pez diablo" o "pleco" en República Dominicana. Se recolectaron muestras de seis sitios en República Dominicana. Se examinaron varios caracteres merísticos y morfométricos, así como otras características externas, incluida la coloración. Los resultados se compararon con la literatura existente sobre peces de la familia Loricariidae. El examen reveló que los especímenes del pez gato acorazado, reportados extraoficialmente como Hypostomus plecostomus, en realidad pertenecen a la especie Pterygoplichthys pardalis (Castelnau, 1855). Se infiere que este pez está establecido en aguas internas dominicanas y se discute la posible presencia de más de una especie de Pterygoplichthys. Este es el primer reporte de esta especie invasora en la isla La Española.

Palabras clave: Pez gato acorazado, Caribe, Hispaniola, invasión, especies introducidas.

\section{INTRODUCTION}

Loricariidae is the most diverse family of catfish (Order Siluriformes) with 1000 species (Fricke et al., 2019). Their most distinctive characteristics are the bony plates that cover their bodies and their sucker-like lips, which provides them with the common name of suckermouth armored catfishes. Although their native range includes South America (except for Chile), 
Costa Rica and Panama (Armbruster \& Page, 2006), several species have been widely introduced to tropical and subtropical freshwater environments worldwide (Orfinger \& Goodding, 2018).

The introduction of these species has been most probably caused by intentional and accidental releases from fish farms and aquariums (Page \& Robins, 2006; Nico et al., 2019). Several negative ecological impacts have been linked to their establishment, such as disruption of food chains, erosion of river banks, declining native fish populations, among others (Hubilla et al., 2007; Hoover et al., 2014).

In the last seven to five years in the Dominican Republic, public attention has focused on the occurrence of armored catfish being caught in freshwater systems. This species has been suggested by fishermen as responsible for a decrease in catches of other species of commercial interest such as Tilapia (Oreochromis spp.) because they supposedly ingest their eggs and juveniles. In the media, the fish has been referred to as Hypostomus plecostomus, pleco, or pez diablo (devil fish), a moniker popularized due to its apparently sinister appearance.

Although local society, as well as governmental agencies have expressed concern for the ecological impacts that this fish might cause and have pointed to them as a serious threat for biodiversity, neither the identity nor the extent of occurrence of this species in the Dominican Republic have been precisely described. Some reports identified the armored catfish as H. plecostomus but no records of this species in Dominican Republic have been published, and vouchers of the armored catfish are minimal as well. In order to establish and report the identity as well as the extent of occurrence of this species, a morphological study on this fish in the Dominican Republic was conducted. Its presumed way of introduction, known distribution and potencial ecological impacts are discussed.

\section{OBJECTIVES}

- To identify the introduced armored catfish currently present in the Dominican Republic.

- To report the extent of occurrence of this fish in the Dominican Republic.

- To discuss the origin of this fish in the Dominican Republic and its potential ecological impacts.

\section{MATERIALS AND METHODS}

Between 2014 and 2019, 19 specimens of the armored catfish were collected from seven different localities in five river basins of the Dominican Republic. These specimens were captured using seines, hand nets, gill nets and manually. Counts of fin elements, as well as morphometric measurements and coloration patterns were performed to obtain a proper species identification. Measurements were taken in millimeters using digital calipers $( \pm 0.1 \mathrm{~mm})$. The identification of the specimens followed Armbruster and Page (2006); observations from Chavez et al. (2006) and $\mathrm{Wu}$ et al. (2011) were also taken into consideration. Examined material is deposited in the ichthyological collection of the Museo Nacional de Historia Natural "Prof. Eugenio de Jesús Marcano" (MNHNSD), Santo Domingo, Dominican Republic. The localities map is based on the collection sites of the vouchers deposited in the museum as well as observations when collection was not possible, made by the author and other collaborators. 


\section{RESULTS}

The morphological identification made in this study, shows that the exotic loricariid fish collected in the Dominican Republic, previously thought to be Hypostomus plecostomus (Linnaeus, 1758), is actually Pterygoplichthys pardalis (Castelnau, 1855), known as “Amazon sailfin catfish".

Pterygoplichthys pardalis is characterized by having 10 or more dorsal-fin rays and a ventrally depressed body, covered with rough, bony plates. The mouth is placed ventrally, forming a sucking disc and it also possesses a pair of maxillary barbels. Lines forming geometric patterns on the head as well as discrete dark ventral spots, rarely forming vermiculations and usually forming leopard-like spots, are also very characteristic of this species (Weber, 1992; Armbruster \& Page, 2006; Page \& Robins, 2006). See Figure 1.

The examined specimens had a wide range in size (31.9-310.0 $\mathrm{mm} \mathrm{SL})$, including both juveniles and adult specimens. The selected morphometric and meristic measurements of the specimens are shown in Tables I and II. These measurements showed little variation with the ones reported for this species in previous studies (Wakida-Kusunoki \& Amador del Angel, 2008; Chavez et al., 2006; Wu et al., 2011). These individuals had little variation in color but it was observed that juveniles had a brownish coloration while adult specimens are darker; ventral spots are more conspicuous in adults.
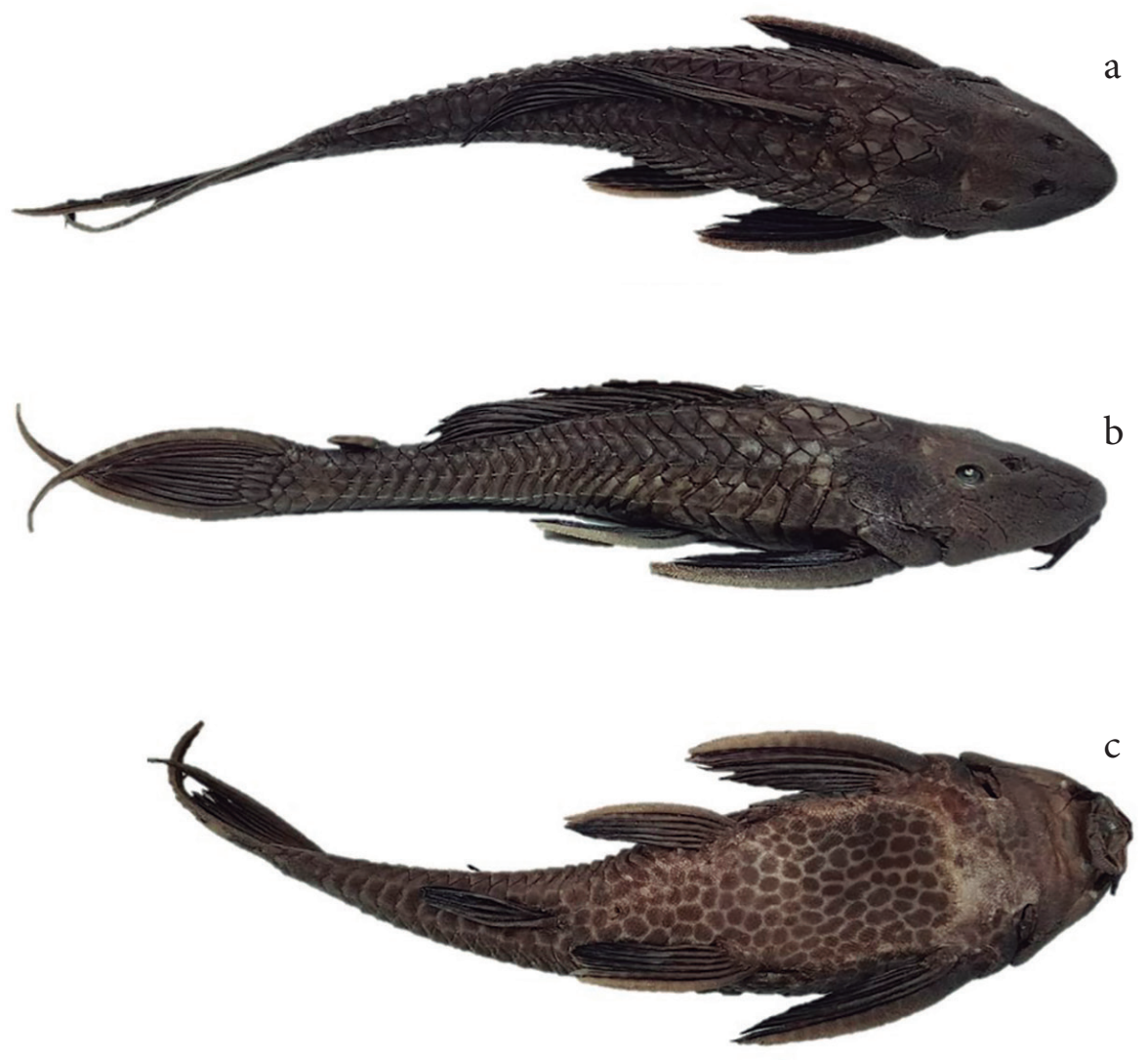

Figure 1. Adult specimen of Pterygoplichthys pardalis. a) dorsal, b) lateral, c) ventral view. Collected in Ozama River, Santo Domingo, Dominican Republic (MNHNSD-22.10556; $320.0 \mathrm{~mm} \mathrm{SL}$ ). 
Table I. Selected morphometric measurements of specimens of Pterygoplichthys pardalis $(\mathrm{N}=19)$ collected in the Dominican Republic

\begin{tabular}{|l|c|c|c|}
\hline Measurement & Range $(\mathrm{mm})$ & Mean $(\mathrm{mm})$ & SD \\
\hline Standard L. & $31.9-310.0$ & 114.3 & 85.4 \\
\hline Predorsal L. & $12.7-104.8$ & 43.3 & 29.1 \\
\hline Head L. & $9.1-70.0$ & 27.1 & 19 \\
\hline Mouth W. & $2.6-16.7$ & 7.5 & 5.3 \\
\hline Snout L. & $5.6-44.5$ & 17.8 & 12.5 \\
\hline Orbit diameter & $2.0-10.1$ & 5.3 & 2.4 \\
\hline Interorbital W. & $3.6-34.0$ & 14.2 & 9.7 \\
\hline Dorsal spine L. & $7.8-71.7$ & 27.3 & 20.9 \\
\hline Dorsal fin base L. & $10.9-101.1$ & 37.2 & 27 \\
\hline Interdorsal L. & $3.1-46.0$ & 17.4 & 13.5 \\
\hline Anal spine L. & $4.3-49.2$ & 18.3 & 13.4 \\
\hline Pectoral spine L. & $7.7-80.9$ & 32.4 & 23.8 \\
\hline Pelvic spine L. & $6.1-65.6$ & 25.2 & 18.3 \\
\hline Postanal L. & $10.5-109.9$ & 40.3 & 30.2 \\
\hline Adipose spine L. & $2.0-21.4$ & 8.4 & 5.8 \\
\hline
\end{tabular}

Table II. Fin rays counts of specimens of Pterygoplichthys pardalis $(\mathrm{N}=19)$ collected in the Dominican Republic

\begin{tabular}{|c|c|c|}
\hline Characters & Count & \% \\
\hline \multirow{3}{*}{ Dorsal fin rays } & 10 & 21.1 \\
\cline { 2 - 3 } & 11 & 52.6 \\
\cline { 2 - 3 } & 12 & 26.3 \\
\hline Anal fin rays & 4 & 100 \\
\hline Caudal fin rays & 14 & 100 \\
\hline Pectoral fin rays & 6 & 100 \\
\hline Pelvic fin rays & 5 & 100 \\
\hline
\end{tabular}

\section{DISCUSSION}

Taxonomy and invasiveness of the group. It has been common to refer to nearly all large-bodied loricariids of the subfamily Hypostominae as Hypostomus plecostomus in the pet trade despite the fact that the species has rarely, if ever, been exported for the pet trade. Species of the genus Pterygoplichthys Gill, 1858, are often confused with those of Hypostomus Lacepède, 1803 (mainly with $H$. plecostomus), but they can be easily distinguished by having more than nine dorsal rays (usually 10-11), while Hypostomus spp., almost always has seven (Armbruster, 2004; Armbruster \& Page, 2006). 
Pterygoplichthys species have been reported as introduced in 21 countries, including the U. S., the Philippines, Taiwan, Mexico, Poland, Israel, India, Turkey, China, Serbia, Vietnam, among others (Orfinger \& Goodding, 2018). The detritivorous and algivorous feeding habits of species in the genus as well as their hardiness, have made them popular in the aquarium trade because they keep the fish tanks free of organic waste and algae. Unfortunately, their large adult sizes have resulted in releases from aquarists, and escapes from fish farms have also been common.

The first established nonnative population was reported from Florida in the United States, in the late 1950s (Fuller et al., 1999). According to Bunkley-Williams et al. (1994), P. multiradiatus has been established since 1990 in several of Puerto Rico's river basins; however; P. pardalis was registered from Puerto Rico in 1999 (Nico et al., 2019), and P. multiradatus was a misidentification. Pterygoplichthys pardalis was also identified from Jamaica and Cuba (Jones, 2008; García-González et al., 2016). No other reports of Pterygoplichthys spp., from the Caribbean region have been issued, except for the present study.

Out of the 15 valid species in the genus, the most popular ones in the pet trade, and therefore the most commonly introduced in the world are $P$. ambrosetti, $P$. pardalis, and $P$. disjunctivus. Although $P$. multiradiatus has been reported as introduced in the past, it is easily identified by having small, separate spots all over the body, and the only specimens examined that could be identified as this are from around Miami, Florida, USA (Jonathan W. Armbruster pers. obs.). P. ambrosetti (formerly referred to as $P$. anisitsi) is the least commonly kept species, and it has light vermiculations on a dark body (vs. dark spots or vermicualtions with a brown background color). $P$. disjunctivus and $P$. pardalis are morphologically and ecologically very similar, the main diagnostic trait being the pattern of ventral spots. $P$. disjunctivus differs from $P$. pardalis in having dark spots coalesced to form a vermiculate pattern on the abdomen (vs. spots or vermiculations of no more than five combines spots in $P$. pardalis) and spots on the head (vs. light lines forming a geometric pattern on the head in P. pardalis), (Weber, 1992; Armbruster \& Page, 2006; Page \& Robins, 2006). All the material examined shows discrete dark ventral spots rarely forming vermiculations and radiating light lines on the head, therefore the identification of the specimens is as P. pardalis, which occurs naturally in the lower, middle, and upper Amazon River basin of Brazil and Peru (Weber, 2003; Fig. 1).

According to Wu et al. (2011) and Godwin et al. (2016), most exotic populations introduced around the world are comprised of hybrids of $P$. pardalis and $P$. disjunctivus with specimens showing pure $P$. pardalis morphologies, pure $P$. disjunctivus morphologies, and intermediate morphologies. This has led to the identification in some countries to sympatric and allopatric populations of both species being identified, as well as intermediate forms, being reported in Mexico (Wakida-Kusunoki \& Amador del Ángel, 2008), Israel (Golani \& Snovsky, 2013), China (Wei et al., 2017), the Philippines (Chavez et al., 2006), Taiwan (Wu et al., 2011), United States (Nico et al., 2012), and India (Bijukumar et al., 2015). In this sense, Wu et al. (2011) found that specimens identified morphologically as $P$. pardalis had $P$. disjunctivus mitochondrial DNA and vice versa, thus suggesting that $P$. disjunctivus is not valid or that most exotic populations might be a product of early hybridization, making identification to the specific level based solely in morphological traits, complicated. Wu et al. (2011) also stated the possibility that the superiority of the hybrids may have helped increase their fitness during invasion, providing better chances of survival and colonization of new habitats.

Even though, the specimens collected in the Dominican Republic corresponds to the $P$. pardalis morphotype, the possibility of some degree of hybridization could not be ruled out. A large collection series of the fish from around the country, complemented with molecular analysis could lead to the identification of other species or more clearly differentiated hybrid swarms. 
It is unlikely that $H$. plecostomus is introduced, as there are no known vouchers of this species in the country, (Jonathan W. Armbruster, pers. obs.) also this species has never been in the pet trade.

Introduction and distribution in the Dominican Republic. There are no records documenting the date and causes of introduction of sailfin catfish in the Dominican Republic. Importation records for pet trade on plecos in the Dominican Republic could not be found, but based on anecdotal information, it is believed that the introduction of the species occurred in the early-2000s. In 2011, Nelson Marcano and other technicians from the Biodiversity Department of the Ministry of Environment and Natural Resources of the Dominican Republic performed multiple confiscations in pet shops around the country, where plecos were first detected. Their first observation in the wild was a few years later, in 2013, in Monte Plata province although it is possible the fish was introduced long before. Most probably, multiple human related introductions in the wild led to the wide and fast spread of this fish in the country. According to Hoover et al. (2014), populations expand rapidly, becoming abundant within 5-10 years of initial detection and presumed introduction.

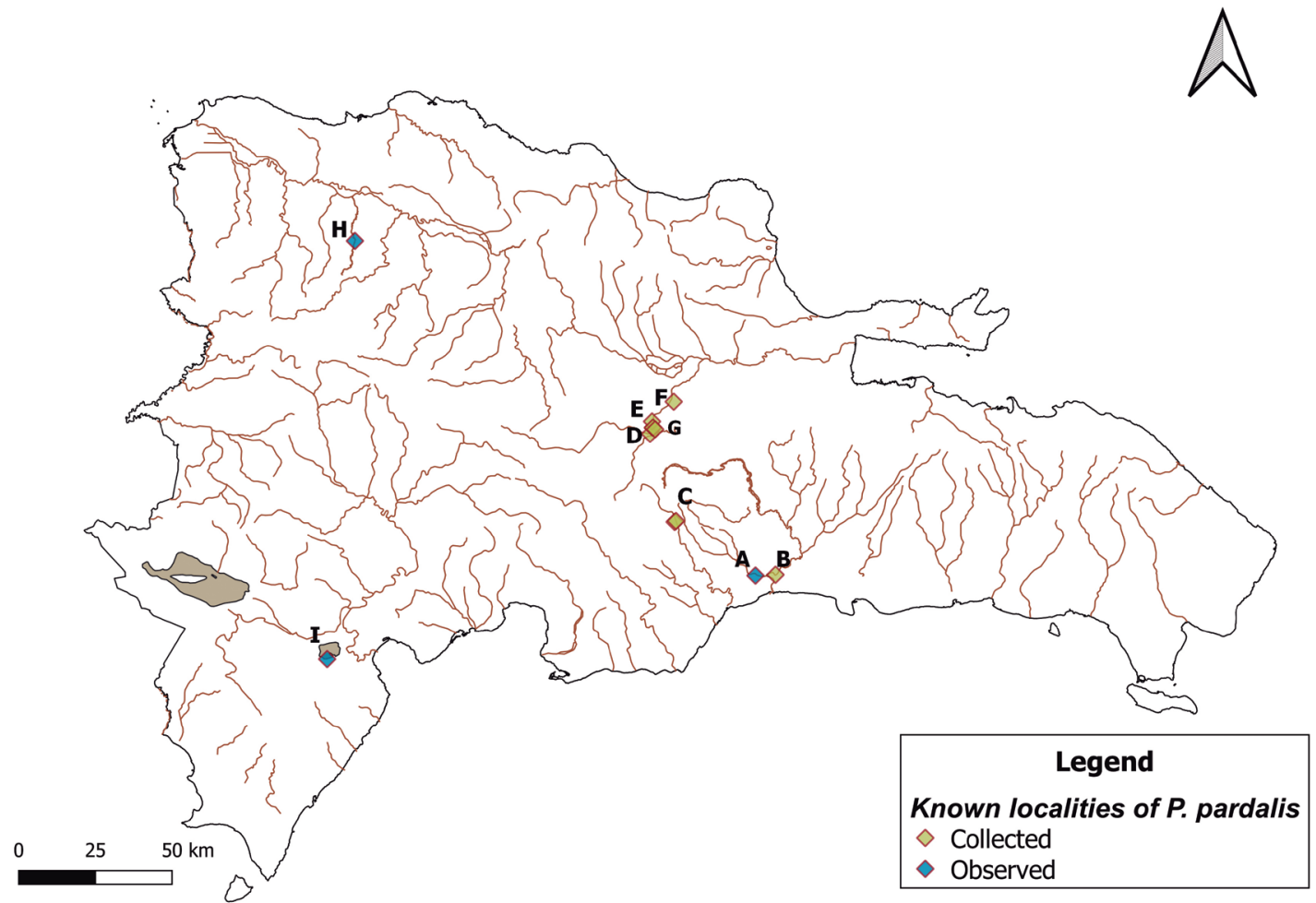

Figure 2. Map of localities of collected and observed specimens of Pterygoplichthys pardalis in the Dominican Republic. A, Isabela River. B, Ozama River, both in Santo Domingo province. C, Haina River, San Cristobal Province. D, Maimon River, Sanchez Ramirez province. E, Hatillo Reservoir, Sanchez Ramirez province. F, Yuna River, Sanchez Ramirez province. G, Margajita River, Sanchez Ramirez province. H, Gurabo River, Santiago Rodriguez province. I, Cabral Lagoon, Barahona province. Some points are overlapped. 


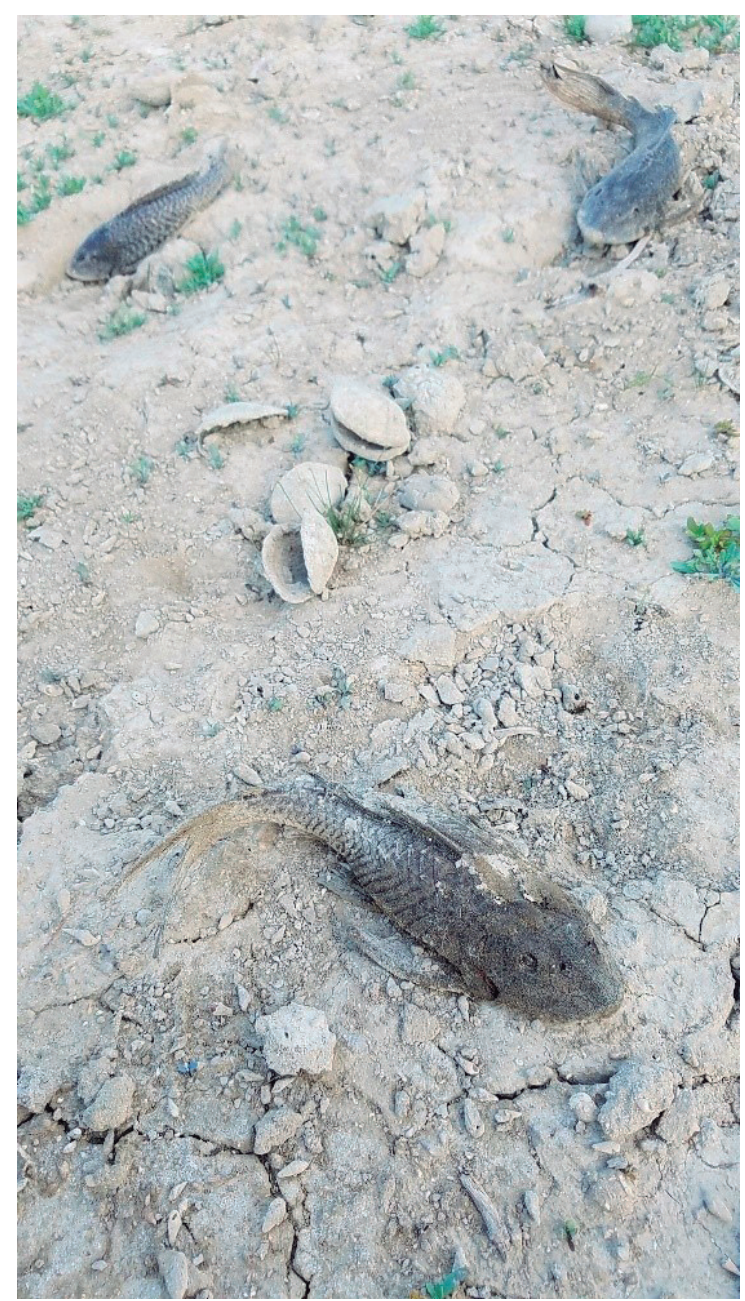

Figure 3. Carcasses of Pterygoplichthys pardalis in Cabral Lagoon, Barahona province, during runoff caused by drought. Photo by M.A. Landestoy.

Even though sightings of Pterygoplichthys specimens have been reported from all over the country in national media, the occurrence of more than one species is not ruled out. Since closer examination is needed to verify the identification as $P$. pardalis, just the ones examined in this study as well as observations made by the author and collaborators, when collection was not possible, are taken in consideration in the map of localities (Fig. 2).

In some sites, locals have reported the presence of hundreds of this fish and it constitutes one of the main catches in traps and gill nets of fishermen of the Ozama and Isabela rivers in Santo Domingo. In the last year, there has been a severe drought in the Dominican Republic causing severe runoff in many rivers, streams, and reservoirs, and as a result, dozens of carcasses of armored catfishes have been seen in some locations, such as in the Hacienda Estrella Reservoir in Monte Plata province and in Cabral Lagoon in Barahona province (Fig. 3). Even though across their native range of occurrence, armored catfishes are consumed in various forms (Moroni et al., 2015), in the Dominican Republic, fishermen and consumers show little interest in this species, so it is usually discarded when caught. 
Based on the high number of sightings around the country and the high abundance reported in those sites, as well as the fish that have been collected in several of the main river basins, reservoirs and lagoons of the country, it is inferred that $P$. pardalis is already established and widely distributed in the inland water systems of the Dominican Republic.

Potential ecological and socioeconomic impacts. Many characteristics of the group make them very invasive and virtually impossible to exterminate once established. Fecundity of loricariids is from 500 to 3000 eggs per female, they provide parental care as well. They are facultative air breathers (Armbruster, 1998), highly tolerant of polluted and hypoxic waters and can adapt rapidly to varying water quality conditions; their armored body and strong spines offer protection against potential predators (Mendoza-Alfaro et al., 2009). The air-holding structure is the stomach, and it is always full of air allowing the fishes to use the water column unlike most loricariid catfishes which are exclusively found attached to the substrate (Jonathan W. Armbruster, pers. obs.). Pterygoplichthys spp. are also capable of surviving mesohaline conditions (up to $10 \mathrm{ppt}$ salinity) for extended periods of time, allowing for the use of estuarine and coastal areas for dispersal (Capps et al., 2011).

Various serious socioeconomic and ecological implications have been linked to the establishment of Pterygoplichthys species in nonnative ranges. Male Pterygoplichthys dig holes in banks as nests, and in Hawaii and Puerto Rico. These burrows have been linked to erosion, sedimentation, and elevated turbidity in reservoirs and streams (Devick, 1989; Bunkley-Williams et al., 1994). Pterygoplichthys species in the Philippines and in Florida are thought to be competing with native fishes for resources and may be altering food web dynamics (Hubilla et al., 2007; Hoover et al., 2014). In Lake Okeechobee, Florida, population increases of $P$. multiradiatus between 2005 and 2006 were associated with reduced Catch Per Unit Effort of native fishes (Mendoza-Alfaro et al., 2009).

Pterygoplichthys species graze on algae, benthic organisms, and detritus, and they may potentially affect indigenous invertebrate communities as well as alter the ecology of a water body by reducing the amount of energy available to other herbivores (Nico et al., 2009). They might consume the eggs of native species of fish and invertebrates as well as compete for food with other herbivores, causing declines in the abundance and biodiversity of fish and invertebrates populations (Hoover et al., 2014). An experimental study in Thailand showed that $P$. pardalis in aquarium conditions, fed on eggs and fry larvae of $O$. niloticus (Chaichana \& Jongphadungkiet, 2012). It is possible they predate on eggs of species that are important for the river fisheries of the country. They also could feed on the eggs of other native egg-laying fishes such as the ones of the genus Rivulus, Eleotris, Dormitator, Gobiomorus and Nandopsis.

Sailfin catfishes have been observed burrowing in the nests of blue tilapia (O. aureus), this disturbance could lead to the fish abandoning the nest therefore reducing reproductive success. (Hoover et al., 2014). In the Dominican Republic no risk assessment on the impact of this species has been done, but local fishermen consider it responsible for the decline in catches of commercial species, which has had a direct impact in the quality of life of the communities that depend on fisheries.

Recommendations. Eradication of this species, once established, is not typically feasible (Hill \& Sowards, 2015), hence the aim should be preventing future introductions of this and other potential invasive species in the wild. The best way of accomplishing this is by developing policies that hinder the introduction of potential invasive species and educating the public on the importance of not releasing unwanted aquarium fishes into natural water bodies. 
Extensive monitoring in particularly vulnerable ecosystems such as mangroves, estuaries, lagoons, and streams must be made across the country. In particular, a combination of collection and environmental DNA (eDNA) sampling might generate important insights. eDNA is useful in detecting the early stages of an invasion when traditional sampling methods cannot yet detect the presence of a species (Ardura et al., 2015; Dougherty et al., 2016). Early detection would be more likely to aid in the succesful contention and eradication of the invasives.

The governmental authorities along with civil society (mainly the most impacted sectors such as fishermen) must make an assessment of the risks and impacts of this species as well as present a management plan. The economic feasibility of exploitation of the fish should be evaluated. The use of the fish in various ways should be promoted, in order to take advantage of their abundance and as a way of possibly reducing their numbers in specific locations. The feasibility of this fish for human consumption in the country should be studied. Although the species is edible, Chavez et al. (2006) did not recommend the consumption of Pterygoplicthys spp., collected in a lagoon in the Philippines, as food due to potential bioaccumulation of heavy metals and E. coli. However, in some areas of South America, Pterygoplichthys species are among the most common fishes collected by fishers (Garcia et al., 2009; Castello et al., 2013).

This fish could be used for the production of commercial animal food, as has been recommended in Thailand (Panase et al., 2018). In the Philippines, Hubilla et al. (2007) recommended its use as fertilizer as well as the skin for home décor and crafting.

\section{CONCLUSIONS}

The Amazon sailfin catfish (Pterygoplicthys pardalis) is inferred to be established and widely distributed in the Dominican Republic and presents many potential threats to biodiversity and fisheries. This constitutes the first report of the species for Hispaniola. Dates and cause of introduction are uncertain but it might be the result of an intentional aquarium release. The possibility of more than one species of the genus presented is discussed as well as the need for a management plan for the control of the species.

\section{ACKNOWLEDGEMENTS}

To Larry M. Page from the Florida Museum of Natural History, Gainesville, FL, USA, that verified the identification of the specimens and shared important papers and insights about this species. To Ingo Schlupp and Rodet Rodríguez-Silva from The Oklahoma University, Norman, USA and Francis Reyes as well, for their suggestions for the best presentation of this manuscript. To Miguel Ángel Landestoy for sharing important field observations and photos and to Alfredo Dalmau and Nelvison de Jesus for their assistance in some field explorations.

\section{LITERATURE CITED}

Ardura, A., A. Zaiko, J. L. Martinez, A. Samulioviene, A. Semenova, \& E. Garcia-Vazquez. 2015. eDNA and specific primers for early detection of invasive species-A case study on the bivalve Rangia cuneata, currently spreading in Europe. Marine Environmental Research, 112, 48-55 pp.

Armbruster, J. W. 1998. Modifications of the digestive tract for holding air in loricariid and scoloplacid catfishes. Copeia, 1998: 663-675. 
Armbruster, J. W. 2004. Phylogenetic relationships of the suckermouth armoured catfishes (Loricariidae) with emphasis on the Hypostominae and the Ancistrinae. Zoological Journal of the Linnean Society, 141 (1): 1-80. Available: https://doi.org/10.1111/j.10963642.2004.00109.x.

Armbruster, J. W., \& L. M. Page. 2006. Redescription of Pterygoplichthys punctatus and description of a new species of Pterygoplichthys (Siluriformes: Loricariidae). Neotropical Ichthyology, 4(4): 401-410.Available:https://doi.org/10.1590/S1679-62252006000400003.

Bunkley-Williams L., E. H. Williams Jr, C.G. Lilystrom, I. Corujo-Flores, A. J. Zerbi, C. Aliaume, \& T. N. Churchill. 1994. The South American sailfin armored catfish, Liposarcus multiradiatus (Hancock), a new exotic established in Puerto Rican fresh waters. Caribbean Journal of Science, 30 (1-2): 90-94.

Bijukumar, A., R. Smrithy, U. Sureshkumar, \& S. George. 2015. Invasion of South American suckermouth armoured catfishes Pterygoplichthys spp. (Loricariidae) in Kerala, India - a case study. Journal of Threatened Taxa, 7 (3): 6987-6995. Available: https://doi.org/10.11609/ JoTT.04133.6987-95.

Capps, K. A., L. G. Nico, M. Mendoza-Carranza, W. Arévalo-Frías, A. J. Ropicki, S. A. Heilpern, \& R. Rodiles-Hernández. 2011. Salinity tolerance of non-native suckermouth armoured catfish (Loricariidae: Pterygoplichthys) in south-eastern Mexico: implications for invasion and dispersal. Aquatic Conservation: Marine and Freshwater Ecosystems, 21 (6): 528-540. Available: https://doi.org/10.1002/aqc.1210.

Castello, L., D. G. McGrath, C. C. Arantes, \& O. T. Almeida. 2013. Accounting for heterogeneity in small-scale fisheries management: the Amazon case. Marine Policy, 38: 557-565.

Chaichana, R., \& S. Jongphadungkiet. 2012. Assessment of the invasive catfish Pterygoplichthys pardalis (Castelnau, 1855) in Thailand: ecological impacts and biological control alternatives. Tropical Zoology, 25 (4): 173-182. Available: https://doi.org/10.1080/03946 975.2012.738494.

Chavez, J. M., R. M. De La Paz, S. K. Manohar, R. C. Pagulayan, \& J. R. Carandang VI. 2006. New Philippine record of south american sailfin catfishes (Pisces: Loricariidae). Zootaxa, 1109 (1): 57. Available: https://doi.org/10.11646/zootaxa.1109.1.6.

Devick, W. S. 1989. Disturbances and fluctuations in the Wahiawa Reservoir ecosystem. Project F-14-R-13, Job 4, Study I'. Division of Aquatic Resources, Hawaii Department of Land and Natural Resources.

Dougherty, M. M., E. R. Larson, M. A. Renshaw, C. A. Gantz, S. P. Egan, D. M. Erickson, \& D. M. Lodge. 2016. Environmental DNA (eDNA) detects the invasive rusty crayfish Orconectes rusticus at low abundances. Journal of Applied Ecology, 53 (3): $722-732$ pp.

Fricke, R., W. N. Eschmeyer, \& J. D. Fong. 2019. Eschmeyer's catalog of fishes: species by family/subfamily. Available: http://researcharchive.calacademy.org/research/ichthyology/ catalog/SpeciesByFamily.asp (accessed: 20 Dec 2019).

Fuller P. L., L. G. Nico, \& J. D. Williams 1999. Nonindigenous Fishes Introduced into Inland Waters of the United States. American Fisheries Society, Special Publication, 27. Bethesda: American Fisheries Society. 
Garcia, A., S. Tello, G. Vargas, \& F. Duponchelle. 2009. Patterns of commercial fish landings in the Loreto region (Peruvian Amazon) between 1984 and 2006. Fish physiology and biochemistry, 35 (1): 53-67.

García-González, A., F. B. Riverón-Giró, \& E. Barba. 2016. Primer registro para Cuba del pez invasor Pterygoplichthys pardalis (Siluriformes: Loricariidae). Revista Cubana de Ciencias Biológicas, 5 (2): 1-6.

Godwin, J. C., D. A. Steen, D. Werneke, \& J. W. Armbruster. 2016. Two significant records of exotic tropical freshwater fishes in southern Alabama. Southeastern Naturalist, 15 (4): 57-60.

Golani, D., \& G. Snovsky. 2013. Occurrence of suckermouth armored catfish (Siluriformes, Loricariidae, Pterygoplichthys) in inland waters of Israel. BioInvasions Records, 2 (3): 253-256. Available: https://doi.org/10.3391/bir.2013.2.3.13.

Hill, J. E., \& J. Sowards. 2015. Successful eradication of the non-native loricariid catfish Pterygoplichthys disjunctivus from the Rainbow River, Florida. Management of Biological Invasions, 6 (3): 311-317.

Hoover, J. J., C. E. Murphy, \& K. J. Killgore. 2014. Aquatic Nuisance Species Research Program. Ecological Impacts of Suckermouth Catfishes (Loricariidae) in North America: A Conceptual Model. Volume 14-1, March 2014. Army Engineer Research and Development Center Vicksburg MS Aquatic Nuisance Species Program.

Hubilla, M., F. Kis, \& J. Primavera. 2007. Janitor fish Pterygoplichthys disjunctivus in the Agusan Marsh: a threat to freshwater biodiversity. Journal of Environmental Science and Management, 10 (1): 10-23.

Jones, A. D. 2008. Suckermouth catfish (Pterygoplichthys pardalis). Aliens of Xamayca, 1: 1-4.

Mendoza-Alfaro, R. E., B. Cudmore, R. Orr, S. C. Balderas, W. R. Courtenay, P. K. Osorio, N. Mandrak, P. A. Torres, M. A. Damian, C. E. Gallardo, A. G. Sanguines, G. Greene, D. Lee, A. Orbe-Mendoza, C. R. Martinez, \& O. S. Arana. 2009. Trinational Risk Assessment Guidelines for Aquatic Alien Invasive Species: Test Cases for the Snakeheads (Channidae) and Armored Catfishes (Loricariidae) in North American Inland Waters. Commission for Environmental Cooperation, Montreal (Quebec), Canadá, 101 pp.

Moroni, F. T., A. C. Ortega, R. B. Moroni, B. Mayag, R. S. D. Jesus, \& E. Lessi. 2015. Limitations in decision context for selection of amazonian armoured catfish acari-bod (Pterygoplichthys pardalis) as candidate species for aquaculture. International Journal of Fisheries and Aquaculture, 7 (8): 142-150.

Nico, L., P. Butt, G. Johnston, H. Jelks, M. Kail, \& S. Walsh. 2012. Discovery of South American suckermouth armored catfishes (Loricariidae, Pterygoplichthys spp.) in the Santa Fe River drainage, Suwannee River basin, USA. BioInvasions Records, 1 (3): 179-200. Available: https://doi.org/10.3391/bir.2012.1.3.04.

Nico, L. G., H. L. Jelks, \& T. Tuten. 2009. Non-native suckermouth armored catfishes in Florida: description of nest borrows and burrow colonies with assessment of shoreline conditions. Engineer Research and Development Center Vicksburg MS Environmental Lab Aquatic Nuisance Species Program. 
Nico, L. G., M. Cannister, \& M. Neilson. 2019. Pterygoplichthys pardalis (Castelnau, 1855). U.S. Geological Survey, Nonindigenous Aquatic Species Database, Gainesville, Florida. Available in: https://nas.er.usgs.gov/queries/FactSheet.aspx?SpeciesID=769. Electronic version accessed August, $23^{\text {rd }} 2019$.

Orfinger, A. B., \& D. D. Goodding. 2018. The global invasion of the suckermouth armored catfish genus Pterygoplichthys (Siluriformes: Loricariidae): Annotated list of species, distributional summary, and assessment of impacts. Zoological Studies, 57 (7): 2018-57, doi: 10.6620/ZS.2018.57-07.

Page, L. M., \& R. H. Robins. 2006. Identification of sailfin catfishes (Teleostei: Loricariidae) in southeastern Asia. The Raffles Bulletin of Zoology, 54 (2): 455-457.

Panase, P., S. Uppapong, S. Tuncharoen, J. Tanitson, K. Soontornprasit, \& P. Intawicha. 2018. Partial replacement of commercial fish meal with Amazon sailfin catfish Pterygoplichthys pardalis meal in diets for juvenile Mekong giant catfish Pangasianodon gigas. Aquaculture Reports, 12: 25-29. Available: https://doi.org/10.1016/j.aqrep.2018.08.005.

Wakida-Kusunoki, A. T., \& L. E. Amador del Angel. 2008. Nuevos registros de los plecos Pterygoplichthys pardalis (Castelnau 1855) y P. disjunctivus (Weber 1991) (Siluriformes: Loricariidae) en el Sureste de México. Hidrobiológica, 18 (3): 251-256.

Weber, C. 1992. Revision du genre Pterygoplichthys sensu lato (Pisces, Siluriformes, Loricariidae). Revue Française d'Aquariologie, 19 (1-2): 1-36.

Weber C. 2003. Subfamily Hypostominae (armored catfishes). In: Reis, R. E., S. O. Kullander \& C. J. Ferraris, Jr. (eds.), Check List of the Freshwater Fishes of South and Central America. EDIPUCRS, Porto Alegre. xi +729 pp.

Kullander, \& C. J. Ferraris, Jr. (eds.), Check List of the Freshwater Fishes of South and Central America. EDIPUCRS, Brasil, 351-372 pp.

Wei, H., G. Copp, L. Vilizzi, F. Liu, D. Gu, D. Luo, M. Xu, X. Mu, \& Y. Hu. 2017. The distribution, establishment and life-history traits of non-native sailfin catfishes Pterygoplichthys spp. in the Guangdong Province of China. Aquatic Invasions, 12 (2): 241-249. Available: https://doi.org/10.3391/ai.2017.12.2.11.

Wu, L., C. Liu, \& S. Lin. 2011. Identification of exotic sailfin catfish species (Pterygoplichthys, Loricariidae) in Taiwan based on morphology and mtDNA sequences. Zoological Studies, 50: $235-246$.

[Recibido: 28 de octubre, 2019. Aceptado para publicación: 19 de abril, 2020] 